\title{
EKSPLORASI, ISOLASI DAN SELEKSI JAMUR ENTOMOPATOGEN PLUTELLA XYLOSTELLA (LEPIDOPTERA: YPONOMEUTIDAE) PADA PERTANAMAN CAISIN (BRASSICA CHINENSIS) DI SUMATERA SELATAN
}

\author{
Haperidah Nunilahwati ${ }^{1}$, Siti Herlinda ${ }^{2}$, Chandra $\operatorname{Irsan}^{2}$ \& Yulia Pujiastuti ${ }^{2}$ \\ ${ }^{1}$ Program Studi Doktor Ilmu Pertanian, Program Pascasarjana, Universitas Sriwijaya \\ Jl. Padang Selasa No. 524, Bukit Besar, Palembang \\ E-mail: haperidah@yahoo.com \\ ${ }^{2}$ Jurusan Hama dan Penyakit Tumbuhan, Fakultas Pertanian, Universitas Sriwijaya \\ Jl. Raya Palembang-Prabumulih Km 32, Ogan Ilir, Inderalaya 30662.
}

\begin{abstract}
Exploration, isolation and selection entomopathogenic fungi infectious to Plutella xylostella (Lepidoptera: Yponomeutidae) on green mustard (Brassica chinensis) crop in South Sumatra. Plutella xylostella is the most destructive insect pests of the brassicae family. The research objective was to explore, isolate and select entomopathogenic fungi as biological agents for control of $P$. xylostella. This study used 20 fungal isolates originating from soil and infected insects around the farmers' field in lowland and highland of South Sumatra. The fungal isolates were tested to third instar larvae of $P$. xylostella. The suspension of entomopathogenic fungus was topical inoculated with a density of $1 \times 10^{6} \mathrm{conidia} \mathrm{ml}^{-1}$ on the test insect and five replicates. The result showed that the highest (83\%) and the lowest (41\%) mortality of the larvae $P$. xylostella was induced by fungal BPluS and BNIPTr, respectively. Moreover, the shortest (2.1 days) and the highest (4.3 days) lethal times of the infected host were induced by fungal BPluS and BNIPTr, respectively.
\end{abstract}

Key words: B. bassiana, M. anisopliae, entomopathogen, P. xylostella

\section{ABSTRAK}

Eksplorasi, isolasi dan seleksi jamur entomopatogen Plutella xylostella (Lepidoptera: Yponomeutidae) pada pertanaman caisin (Brassica chinensis) di Sumatera Selatan. P. xylostella merupakan serangga hama yang sangat destruktif pada tanaman famili Brassicae. Tujuan penelitian adalah eksplorasi, isolasi dan seleksi jamur entomopatogen yang patogenik sebagai agens hayati untuk mengendalikan P. xylostella. Isolat yang digunakan pada penelitian adalah 20 isolat yang berasal dari tanah dan serangga yang terinfeksi sekitar pertanaman caisin milik petani didataran rendah dan dataran tinggi Sumatera Selatan. Isolat diuji pada larva $P$. xylostella instar tiga. Aplikasi isolat dilakukan dengan cara meneteskan suspensi jamur entomopatogen dengan kerapatan $1 \times 10^{6} \mathrm{konidia} \mathrm{ml}^{-1}$ secara topikal pada serangga uji dan diulang lima kali. Hasil penelitian menunjukkan mortalitas larva P.xylostella tertinggi berasal dari isolat BPluS yaitu $83 \%$, mortalitas larva P. xylostella terendah berasal dari isolat BNIPTr yaitu $41 \%$, sedangkan $\mathrm{LT}_{50}$ terendah ditemukan pada isolat BPluS yaitu 2,09 hari dan $\mathrm{LT}_{50}$ tertinggi pada isolat BNIPTr yaitu 4,33 hari.

Kata kunci: B. bassiana, M. anisopliae, entomopatogen, P. xylostella

\section{PENDAHULUAN}

Plutella xylostella (L.) (Lepidoptera: Yponomeutidae) lebih dikenal dengan nama diamondback moth (DBM) (Kalshoven, 1981) atau ngengat punggung berlian (Listyaningrum et al., 2003), merupakan serangga kosmopolitan (Wai et al., 2008). $P$. xylostella merupakan serangga hama yang sangat destruktif pada tanaman Brassicaceae atau crucifera (Chan et al., 2008). Persentase kerusakan yang disebabkan hama P. xylostella dapat mencapai $54-83 \%$ (Wang et al., 2004). Hasil survei yang dilakukan oleh
Winasa \& Herlinda (2003) menunjukkan bahwa populasi larva $P$. xylostella di daerah Pagaralam, Sumatera Selatan mencapai 6,99 ekor/tanaman dengan tingkat kerusakan mencapai $27,98 \%$. Sedangkan di kota Palembang, kerusakan akibat serangan DBM menurut Herlinda (2004) dapat mencapai $15,55 \%$ yaitu di desa Sukarami, Talangburuk 15,77\% dan Kenten 11,78\%. Serangan DBM menyebabkan produk tanaman yang dihasilkan tidak laku dijual.

Upaya memenuhi tuntutan konsumen akan produk pertanian yang bebas racun pestisida maka pengendalian hama tanaman dengan menggunakan pestisida perlu 
dikurangi. Salah satu alternatif dalam upaya mengurangi penggunaan pestisida adalah pengendalian hayati. Menurut Krutmuang \& Mekchay (2005), pengendalian hayati tidak akan merusak lingkungan dan tidak mematikan organisme non target, sedangkan menurut Herlinda (2008), pengendalian hayati merupakan bagian dari pengendalian alami. Pengendalian hayati memanfaatkan faktor pengendali yang sudah ada di alam yaitu musuh alami dari organisme yang dikendalikan. Musuh alami tersebut mencakup parasitoid, predator dan patogen.

Agens hayati yang berpotensi dalam mengendalikan hama tanaman adalah jamur entomopatogen; Beauveria bassiana (Deciyanto \& Indrayani, 2008; Herlinda, 2010) dan Metarhizium anisopliae (Ghanbary et al., 2009).

Konidia $B$. bassiana dapat menyebabkan mortalitas tungau mencapai 80-100\% (Deciyanto \& Indrayani, 2008) dan mortalitas Nezara viridula mencapai 70-76\% (Indriyati, 2009). Biopestisida $M$. anisopliae dapat mematikan Locusta mencapai 70\%90\% dalam waktu 14-20 hari (Lomer et al., 2001).

Mendapatkan satu jamur entomopatogen yang patogenik terhadap larva $P$. xylostella asal Sumatera Selatan sangat penting untuk mengendalikan hama $P$. xylostella dan dapat mengurangi dampak negatif dari penggunaan insektisida, karena itu penelitian ini bertujuan mengeksplorasi, isolasi dan menyeleksi jamur entomopatogen yang patogenik terhadap larva $P$. xylostella asal Sumatera Selatan.

\section{METODE PENELITIAN}

Eksplorasi Jamur Entomopatogen. Eksplorasi dilakukan dengan dua metode guna mendapatkan spesies jamur entomopatogen. Pertama, menggunakan umpan serangga (insect bait method) seperti dilakukan Hasyim \& Azwana (2003). Serangga umpan yang digunakan ialah larva Tenebrio monilitor Linn. (ulat Hongkong) instar ketiga yang baru berganti kulit, ulat bambu dan $P$. xylostella instar tiga. Tanah yang digunakan untuk memerangkap jamur entomopatogen diambil secara purposive sampling. Tanah diambil dari pertanaman caisin petani. Tanah tersebut lalu digali sedalam 5-10 cm kemudian diambil sebanyak $1000 \mathrm{~g}$, lalu dimasukan kedalam kantung plastik diberi label berupa lokasi dan tanggal pengambilan sampel. Tanah kemudian diayak dengan ayakan 600 mesh dan dimasukan kedalam nampan plastik berukuran $35 \times 28 \times 7$ $\mathrm{cm}^{2}$ dengan ketebalan tanah $3 \mathrm{~cm}$, setelah itu 20 ekor larva $P$. xylostella, T. monilitor dan ulat bambu dan masing-masing dimasukan kedalam nampan. Kegiatan ini diulang 20 kali. Lalu nampan ditutupi dengan kain puring hitam yang telah dilembabkan. Tiga hari kemudian ulat diperiksa dan yang terinfeksi jamur diisolasi di laboratorium pada ruang laminar air flow yang telah disterilkan dengan alkohol $70 \%$.

Kedua mencari serangga terinfeksi jamur di pertanaman caisin petani. Serangga terinfeksi yang ditemukan dimasukan ke dalam cawan petri plastik berdiameter $9 \mathrm{~cm}$, yang telah dialasi dengan kertas saring, lalu ditutup rapat untuk menghindari kelembaban udara.

Isolasi dan Identifikasi. Larva $P$. xylostella, $T$. monilitor dan ulat bambu yang terinfeksi jamur permukaannya disterilkan dengan natrium hipoklorit $1 \%$ atau alkohol 70\% selama tiga menit. Kemudian dibilas air steril sebanyak tiga kali dan dikeringanginkan diatas kertas saring steril. Lalu serangga tersebut diletakkan dalam cawan petri (diameter $9 \mathrm{~cm}$ ) berisi tissue lembab steril dan diinkubasikan untuk merangsang tumbuhnya jamur. Jamur yang keluar dari tubuh larva P. xylostella diambil dengan jarum inokulasi, dibiakan pada media GYA (Glucose Yeast Agar) dan diinkubasikan selama tujuh hari pada suhu $23-25^{\circ} \mathrm{C}$. Jamur tersebut lalu diidentifikasi berdasarkan bentuk morfologinya, identifikasi menggunakan buku yang ditulis oleh Barnett \& Hunter (1972).

Seleksi Isolat Jamur Entomopatogen. Jamur entomopatogen yang telah ditemukan melalui eksplorasi, di isolasi dan identifikasi selanjutnya diseleksi. Pada pengujian seleksi isolat jamur entomopatogen ini ditambah sebelas isolat terbaik dari hasil penelitian koleksi laboratorium (Tabel 1).

Seleksi dilakukan menggunakan serangga uji, yaitu larva P. xylostella. Perbanyakan larva P. xylostella pada tanaman caisin dilakukan di rumah kaca. Perbanyakan jamur entomopatogen menggunakan media GYA.

Setelah biakan isolat jamur entomopatogen tersedia, lalu dilanjutkan dengan menyeleksi isolat jamur tersebut. Seleksi isolat jamur entomopatogen ini dilakukan seperti metode Herlinda et al., (2008) dalam menyeleksi isolat-isolat $B$. bassiana pada walang sangit. Caranya ialah dengan meneteskan $10 \mu 1$ suspensi jamur entomopatogen dengan kerapatan $1 \times 10^{6}$ konidia $\mathrm{ml}^{-1}$ secara topikal pada serangga uji. Setiap isolat jamur entomopatogen diinokulasi pada 20 ekor larva $P$. xylostella instar ketiga yang baru ganti kulit dan diulang sebanyak lima kali. Nimfa yang telah diaplikasi dengan isolat tadi selanjutnya dipelihara dalam kurungan plastik berbentuk silinder (diameter $9 \mathrm{~cm}$ dan tinggi $30 \mathrm{~cm}$ ) yang bagian atasnya ditutupi kain kasa dan didalamnya 
Tabel 1. Isolat jamur entomopatogen koleksi laboratorium

\begin{tabular}{clll}
\hline \multicolumn{1}{c}{ Isolat } & \multicolumn{1}{c}{ Inang } & Daerah Asal & \multicolumn{1}{c}{ Metode Eksplorasi } \\
\hline B. bassiana & & & \\
BPcMs & Pseusoplusia chalcites & Muarasiban & Mengumpulkan serangga sakit \\
BLePd & Lipaphis erysimi & Pagardin & Mengumpulkan serangga sakit \\
BTmPd & Tenebrio monilitor & Pagardin & Umpan serangga \\
BAgTb & Aphis gossypii & Talangburuk & Mengumpulkan serangga sakit \\
BNIPTr & Nilaparvata lugens & Pantura & Mengumpulkan serangga sakit \\
M.anisopliae & & & \\
MAgPd & Aphis gossypii & Pagardin & Mengumpulkan serangga sakit \\
MTmJr & Tenebrio monilitor & Jarai & Umpan serangga \\
MTmMs & Tenebrio monilitor & Muarasiban & Umpan serangga \\
MTmTr & Tenebrio monilitor & Tanjungraja & Umpan serangga \\
MTmIn & Tenebrio monilitor & Indralaya & Umpan serangga \\
MAgIn & Aphis gossypii & Indralaya & Mengumpulkan serangga sakit \\
\hline
\end{tabular}

terdapat pot tanaman caisin. Setiap 12 jam selama fase larva dicatat jumlah larva yang mati, sedangkan jumlah larva yang tersisa yang membentuk pupa juga dicatat setiap hari hingga semua larva menjadi imago. Begitu juga dengan jumlah larva dan imago abnormal dihitung setiap hari. Jamur entomopatogen yang paling sesuai dan paling efektif untuk $P$. xylostella dicirikan atas paling tingginya mortalitas P. xylostella tersebut.

Analisis Data. Isolat jamur entomopatogen yang ditemukan dianalisis secara diskriptif. Morfologi koloni dan spora ditampilkan dalam bentuk gambar. Data perbedaan mortalitas larva dan persentase nimfa menjadi imago yang disebabkan oleh jamur entomopatogen dianalisis menggunakan Analisis Keragaman (Analysis of Variance). Percobaan masing-masing perlakuan disusun menggunakan Rancangan Acak Lengkap (RAL). Waktu kematian nimfa dianalisis menggunkan $\mathrm{LT}_{50}$ yang perhitungannya menggunakan analisis probit waktu kematian nimfa dengan program SAS-STAT pada SAS 6.12.

\section{HASIL DAN PEMBAHASAN}

Isolat Jamur Entomopatogen. Eksplorasi jamur entomopatogen yang telah dilakukan menemukan 9 isolat jamur entomopatogen $B$. bassiana di sentra produksi sayuran caisin dataran rendah kota Palembang yaitu Suak, Talang Buruk dan Kenten (Tabel 2).

Hasil penelitian menunjukkan metode eksplorasi dengan umpan serangga lebih efektif, karena sebagian besar B. bassiana dan $M$. anisopliae yang didapat berasal dari metode umpan serangga. Hal ini karena tanah merupakan reservoar alami atau habitat utama bagi jamur entomopatogen dan sumber infeksi bagi serangga dilapangan sebagai faktor mortalitas hama secara alami (Deciyanto \& Indrayani, 2008; Nuraida \& Hasyim, 2009). Ditambahkan oleh Herlinda et al., (2008) bahwa jamur entomopatogen yang berasal dari serangga terinfeksi lebih sulit diisolasi karena sering terkontaminasi oleh jamur udara.

Pada umpan serangga yang terserang $B$. bassiana tampak tubuh serangga mengeras, berubah warna menjadi hitam kecoklatan dan juga terdapat masa spora yang berwarna putih (Gambar 1).

Warna koloni semua isolat B. bassiana secara makroskopis adalah putih, sedangkan secara mikroskopis konidia berwarna hialin, berbentuk bulat dan memiliki satu sel. Hal ini mendukung hasil penelitian Suharto et al., (1998) yang menyatakan spora B. bassiana berbentuk bulat, bersel satu, hialin dan terbentuk secara tunggal pada sterigma yang pendek. Sedangkan warna semua isolat $M$. anisopliae secara makroskopis di awal pertumbuhan berwarna putih, kemudian berubah warna menjadi hijau gelap. Secara mikroskopis spora hialin, berbentuk silindris dan membentuk rantai (Gambar 2). Hal ini diperjelas oleh Barnett \& Hunter (1972) yang menyatakan spora $M$. anisopliae bersel satu, hialin, dan berbentuk bulat silinder.

Larva $P$. xylostella yang terinfeksi jamur patogenik menyebabkan serangga kurang aktif, terjadi perubahan warna tubuh dari hitam hingga kecoklatan dan tubuh mengkerut (Gambar 3). Herlinda et al. (2005) melaporkan bahwa gejala yang muncul pada $P$. xylostella terinfeksi jamur patogenik adalah warna tubuh berubah dari hijau menjadi hijau kekuningan dan 
Tabel 2. Isolat jamur entomopatogen hasil eksplorasi asal Sumatera Selatan

\begin{tabular}{llll}
\hline \multicolumn{1}{c}{ Isolat } & \multicolumn{1}{c}{ Inang } & \multicolumn{1}{c}{ Daerah Asal } & \multicolumn{1}{c}{ Metode Eksplorasi } \\
\hline B. bassiana & Plutella xylostella & Suak & Umpan serangga \\
BPluS & Tenebrio monilitor & Suak & Umpan serangga \\
BTmS1 & Ulat bambu & Suak & Umpan serangga \\
BUbS2 & Plutella xylostella & Talang buruk & Umpan serangga \\
BPluTb & Tenebrio monilitor & Talang buruk & Umpan serangga \\
BTmTb1 & Ulat bambu & Talang buruk & Umpan serangga \\
BUbTb2 & Plutella xylostella & Kenten & Umpan serangga \\
BPluKn & Tenebrio monilitor & Kenten & Umpan serangga \\
BTmKn1 & Ulat bambu & Kenten & Umpan serangga \\
BUbKn2 & &
\end{tabular}

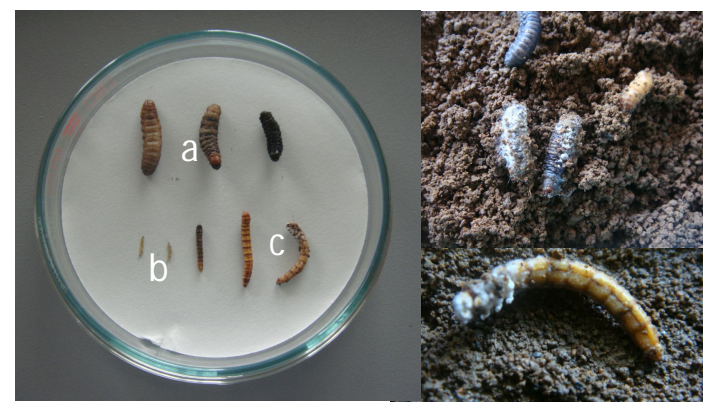

Gambar1.Gejala serangan jamur entomopatogen pada serangga. (a)ulat bambu, (b) P. xylostella, dan (c) T. monilitor.
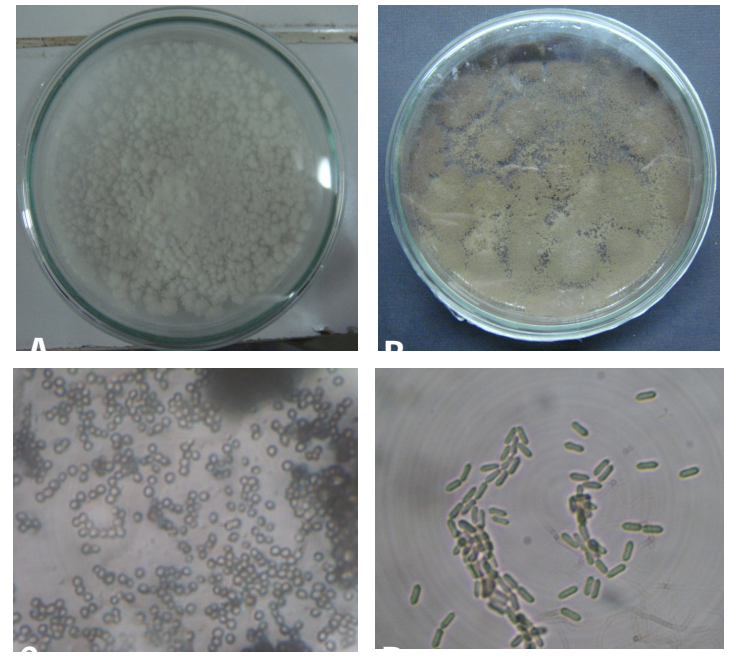

Gambar 2. Koloni jamur B. bassiana (A), koloni jamur M. anisopliae (B), spora B. bassiana pembesaran 40 kali (C), dan spora M. anisopliae pembesaran 40 kali (D).

akhirnya menjadi hitam kecoklatan serta kemampuan makan dan aktivitas pergerakan berkurang.

Perubahan warna tubuh larva $P$. xylostella menjadi hitam akibat aktivitas enzim phenoloksidase yang berperan dalam proses melanisasi terhadap benda asing yang masuk dalam haemocoel (Hung \& Boucias, 1996).
Kerapatan dan Viabilitas Spora Isolat. Kerapatan spora pada isolat-isolat jamur entomopatogen yang diuji memiliki perbedaan antar isolat. Kerapatan spora tertinggi ditemukan pada isolat BPluS yang diisolasi dari P. xylostella berasal dari Suak sebesar $3,64 \times 10^{7}$ konidia/ $\mathrm{ml}$. Sedangkan kerapatan spora terendah pada isolat 
BUbKn2 yang diisolasi dari ulat bambu berasal dari Kenten sebesar $1,84 \times 10^{7} \mathrm{konidia} / \mathrm{ml}$. Isolat BPluS berbeda nyata dengan isolat lain tetapi tidak berbeda nyata dengan isolat BUbS2, BPluTb, dan BLePd (Tabel $3)$.

Kerapatan spora tertinggi pada isolat $M$. anisopliae ditemukan di isolat MAgPd yang diisolasi dari Aphis gossypii berasal dari Pagardin sebesar $3,63 \times 10^{7} \mathrm{konidia} / \mathrm{ml}$. Sedangkan kerapatan spora terendah di isolat MAgIn yang diisolasi dari Aphis gossypii berasal dari Indralaya sebesar 2,28x $10^{7}$ konidia/ $\mathrm{ml}$ (Tabel 4).

Viabilitas spora isolat jamur entomopatogen dari hasil penelitian cukup bervariasi. Viabilitas spora tertinggi terdapat pada isolat BPluS yang diisolasi dari $P$. xylostella asal Suak dengan nilai viabilitas sebesar $31,18 \%$. Sedangkan viabilitas terendah terdapat pada isolat BUbTb2 yang diisolasi dari ulat bambu asal Talang Buruk dan BPluKn yang diisolasi dari P. xylostella asal
Kenten masing-masing viabilitas sebesar 7,23\% (Tabel 5).

Sedangkan pada isolat $M$. anisopliae, viabilitas spora tertinggi terdapat pada isolat MTmMs yang diisolasi dari T. monilitor asal Muarasiban dengan nilai viabilitas sebesar $28,43 \%$ dan berbeda nyata dengan semua isolat (Tabel 6).

Variasi kerapatan dan viabilitas spora dari isolat yang diuji menunjukkan daerah asal isolat dan larva yang diisolasi berbeda. Faktor yang dapat menyebabkan perbedaan kerapatan dan viabilitas spora diantaranya media biakan (Herlinda et al., 2006), suhu dan kelembaban (Sheroze et al., 2003; Suharto et al., 1998; Prayogo et al., 2005) serta faktor genetik (Nuraida \& Hasyim, 2009). Suhu rata-rata selama penelitian adalah $29,48^{\circ} \mathrm{C}$ dan kelembaban nisbih $89,55 \%$. Suhu dan kelembaban tersebut cukup baik untuk pertumbuhan jamur entomopatogen. Menurut Sheroze et al., (2003)
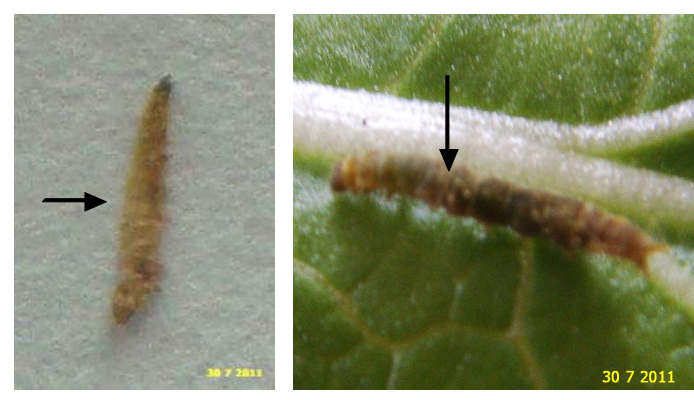

Gambar 3. Gejala serangan jamur entomopatogen pada larva P. xylostella.

Tabel 3. Kerapatan spora isolat B. bassiana

\begin{tabular}{lcc}
\hline \multicolumn{1}{c}{ Isolat } & Kerapatan konidia $\left(10^{7}\right.$ konidia/ml $)$ & BNJ 5\%=0,057 \\
\hline BPluS & $3,64(7,56)$ & $\mathrm{h}$ \\
BTmS1 & $3,46(7,54)$ & $\mathrm{g}$ \\
BUbS2 & $3,64(7,56)$ & $\mathrm{h}$ \\
BPluTb & $3,55(7,55)$ & $\mathrm{gh}$ \\
BTmTb1 & $3,17(7,50$ & $\mathrm{f}$ \\
BUbTb2 & $3,03(7,38)$ & $\mathrm{c}$ \\
BPluKn & $3,14(7,49)$ & $\mathrm{f}$ \\
BTmKn1 & $2,53(7,40)$ & $\mathrm{cd}$ \\
BUbKn2 & $1,84(7,26)$ & $\mathrm{a}$ \\
BPcMs & $2,73(7,44)$ & $\mathrm{e}$ \\
BLePd & $3,53(7,54)$ & $\mathrm{gh}$ \\
BTmPd & $3,22(7,51)$ & $\mathrm{f}$ \\
BAgTb & $2,59(7,41)$ & $\mathrm{d}$ \\
BNIPTr & $2,29(7,36)$ & $\mathrm{b}$ \\
\hline
\end{tabular}

Angka diikuti oleh huruf yang sama pada kolom yang sama berbeda tidak nyata pada taraf uji BNJ 5\%. Data dalam kurung merupakan data transformasi $\log \mathrm{x}$. 
Tabel 4. Kerapatan spora isolat M. anisopliae

\begin{tabular}{ccc}
\hline Isolat & Kerapatan konidia $\left(10^{7}\right.$ konidia/ml $)$ & BNJ 5\%=0,011 \\
\hline MAgPd & $3,63(7,56)$ & $\mathrm{f}$ \\
MTmJr & $3,24(7,51)$ & $\mathrm{d}$ \\
MTmMs & $3,33(7,52)$ & $\mathrm{e}$ \\
MTmTr & $2,73(7,44)$ & $\mathrm{c}$ \\
MTmIn & $2,44(7,39)$ & $\mathrm{b}$ \\
MAgIn & $2,28(7,36)$ & $\mathrm{a}$ \\
\hline
\end{tabular}

Angka diikuti oleh huruf yang sama pada kolom yang sama berbeda tidak nyata pada taraf uji BNJ 5\%. Data dalam kurung merupakan data transformasi $\log \mathrm{x}$.

Tabel 5. Viabilitas spora isolat B. bassiana

\begin{tabular}{lcc}
\hline Isolat & Viabilitas spora $(\%)$ & BNJ $5 \%=8,21$ \\
\hline BPluS & 31,18 & $\mathrm{~g}$ \\
BTmS1 & 17,10 & $\mathrm{cde}$ \\
BUbS2 & 22,19 & ef \\
BPluTb & 19,04 & $\mathrm{de}$ \\
BTmTb1 & 27,70 & $\mathrm{fg}$ \\
BUbTb2 & 7,23 & $\mathrm{a}$ \\
BPluKn & 7,23 & $\mathrm{a}$ \\
BTmKn1 & 10,82 & $\mathrm{abc}$ \\
BUbKn2 & 13,13 & $\mathrm{abcd}$ \\
BPcMs & 7,62 & $\mathrm{ab}$ \\
BLePd & 8,53 & $\mathrm{ab}$ \\
BTmPd & 30,39 & $\mathrm{fg}$ \\
BAgTb & 15,45 & $\mathrm{bcde}$ \\
BNIPTr & 14,63 & $\mathrm{abcde}$ \\
\hline
\end{tabular}

Angka diikuti oleh huruf yang sama pada kolom yang sama berbeda tidak nyata pada taraf uji BNJ 5\%.

Tabel 6. Viabilitas spora isolat M. anisopliae

\begin{tabular}{ccc}
\hline Isolat & Viabilitas spora $(\%)$ & BNJ 5\%=7,13 \\
\hline MAgPd & 8,03 & a \\
MTmJr & 7,98 & a \\
MTmMs & 28,43 & b \\
MTmTr & 10,77 & a \\
MTmIn & 8,26 & a \\
MAgIn & 8,00 & a \\
\hline
\end{tabular}

Angka diikuti oleh huruf yang sama pada kolom yang sama berbeda tidak nyata pada taraf uji BNJ 5\%.

suhu bagi pertumbuhan jamur entomopatogen adalah $30^{\circ} \mathrm{C}$ dan kelembaban $80 \%$.

Mortalitas Larva $P$. xylostella setelah Aplikasi $B$. bassiana dan M. anisopliae. Semua isolat B. bassiana yang diujikan menyebabkan mortalitas pada larva $P$. xylostella dan menunjukkan mortalitas yang beragam.
Mortalitas larva P. xylostella tertinggi berasal dari isolat BPluS yaitu $83 \%$ dan mortalitas terendah berasal dari isolat BNIPTr yaitu $41 \%$ (Tabel 7).

Pada isolat $M$. anisopliae mortalitas larva $P$. xylostella tertinggi berasal dari isolat MAgPd yaitu $82 \%$ dan mortalitas terendah berasal dari isolat MAgIn yaitu $46 \%$ (Tabel 8). 
Mortalitas larva P. xylostella oleh jamur patogenik dapat disebabkan karena kontak konidia pada tubuh larva (Surtikanti \& Yasin, 2009) dan faktor suhu dan kelembaban (Mahr et al., 2001). Menurut Surtikanti \& Yasin (2009), peningkatan mortalitas terjadi apabila antara larva dengan spora jamur terjadi kontak. Pada saat terjadi kontak, spora membentuk tabung kecambah dan mensekresikan enzim untuk melunakan kutikula larva sehingga spora dapat masuk ke tubuh larva. Pertumbuhan spora dalam tubuh larva akan menyebabkan terganggunya seluruh aktivitas organ dan berakibat pada kematian larva. Disamping itu juga jamur B. bassiana memproduksi toksin Beauvericin yang mengakibatkan gangguan pada fungsi hemolimfa, gangguan inti sel serangga inang dan hilang kesadaran serta kerusakan jaringan tubuh secara menyeluruh (Deciyanto \& Indrayani, 2008; Ahmad et al., 2008).

Persentase Pupa Menjadi Imago. Persentase pupa menjadi imago berhubungan erat dengan mortalitas pupa. Semakin tinggi mortalitas pupa maka semakin sedikit imago yang muncul. Persentase pupa menjadi imago terendah pada isolat B.bassiana terdapat pada isolat BPluS sebesar 16\% (Tabel 9) sedangkan pada isolat $M$. anisopliae terdapat pada isolat MAgPd sebesar 15\% (Tabel 10).

Adanya larva yang mampu menjadi pupa dan kemudian menjadi imago setelah aplikasi jamur entomopatogen diduga karena jamur entomopatogen tidak dapat berkembang dalam tubuh larva P. xylostella.

Tabel 7. Mortalitas larva P. xylostella setelah aplikasi B. bassiana

\begin{tabular}{lcr}
\hline Isolat & Mortalitas larva $(\%)$ & BNJ $5 \%=0,71$ \\
\hline BPluS & $83(5,22)$ & $\mathrm{f}$ \\
BTmS1 & $66(4,66)$ & def \\
BUbS2 & $79(5,07)$ & $\mathrm{f}$ \\
BPluTb & $70(4,77)$ & ef \\
BTmTb1 & $46(3,86)$ & $\mathrm{bc}$ \\
BUbTb2 & $44(3,79)$ & $\mathrm{b}$ \\
BPluKn & $42(3,70)$ & $\mathrm{b}$ \\
BTmKn1 & $50(4,04)$ & $\mathrm{bcd}$ \\
BUbKn2 & $42(3,70)$ & $\mathrm{b}$ \\
BPcMs & $63(4,55)$ & $\mathrm{cdef}$ \\
BLePd & $81(5,15)$ & $\mathrm{f}$ \\
BTmPd & $57(4,31)$ & bcde \\
BAgTb & $55(4,24)$ & bcde \\
BNIPTr & $41(3,66)$ & $\mathrm{b}$ \\
Kontrol & $0(0,06)$ & $\mathrm{a}$ \\
\hline
\end{tabular}

Angka diikuti oleh huruf yang sama pada kolom yang sama berbeda tidak nyata pada taraf uji BNJ 5\%. Data dalam kurung merupakan data transformasi arcsine akar $\mathrm{x}$.

Tabel 8. Mortalitas larva P. xylostella setelah aplikasi M. anisopliae

\begin{tabular}{lcc}
\hline Isolat & Mortalitas larva $(\%)$ & BNJ $5 \%=0,41$ \\
\hline MAgPd & $82(5,19)$ & $\mathrm{c}$ \\
MTmJr & $72(4,08)$ & $\mathrm{c}$ \\
MTmMs & $71(4,83)$ & $\mathrm{c}$ \\
MTmTr & $52(4,08)$ & $\mathrm{b}$ \\
MTmIn & $52(4,13)$ & $\mathrm{b}$ \\
MAgIn & $46(3,89)$ & $\mathrm{b}$ \\
Kontrol & 0 & $\mathrm{a}$ \\
\hline
\end{tabular}

Angka diikuti oleh huruf yang sama pada kolom yang sama berbeda tidak nyata pada taraf uji BNJ 5\%. Data dalam kurung merupakan data transformasi arcsine akar $\mathrm{x}$. 
Tabel 9. Persentase pupa P.xylostella menjadi imago setelah aplikasi B. bassiana

\begin{tabular}{lcc}
\hline Isolat & Pupa menjadi imago $(\%)$ & BNJ $5 \%=0,91$ \\
\hline BPluS & $16(2,28)$ & $\mathrm{a}$ \\
BTmS1 & $32(3,22)$ & $\mathrm{bcd}$ \\
BUbS2 & $19(2,36)$ & $\mathrm{ab}$ \\
BPluTb & $25(2,81)$ & $\mathrm{abc}$ \\
BTmTb1 & $46(3,87)$ & $\mathrm{de}$ \\
BUbTb2 & $54(4,20)$ & $\mathrm{e}$ \\
BPluKn & $53(4,16)$ & $\mathrm{e}$ \\
BTmKn1 & $45(3,83)$ & $\mathrm{de}$ \\
BUbKn2 & $46(3,87)$ & $\mathrm{de}$ \\
BPcMs & $36(3,43)$ & $\mathrm{cde}$ \\
BLePd & $18(2,39)$ & $\mathrm{ab}$ \\
BTmPd & $43(3,74)$ & $\mathrm{cde}$ \\
BAgTb & $38(3,52)$ & $\mathrm{cde}$ \\
BNIPTr & $53(4,17)$ & $\mathrm{e}$ \\
Kontrol & $0(5,74)$ & $\mathrm{f}$ \\
\hline
\end{tabular}

Angka diikuti oleh huruf yang sama pada kolom yang sama berbeda tidak nyata pada taraf uji BNJ 5\%. Data dalam kurung merupakan data transformasi arcsine akar $\mathrm{x}$.

Tabel 10. Persentase pupa P. xylostella menjadi imago setelah aplikasi M. anisopliae

\begin{tabular}{ccc}
\hline Isolat & Pupa menjadi imago $(\%)$ & BNJ $5 \%=0,58$ \\
\hline MAgPd & $15(2,20)$ & $\mathrm{a}$ \\
MTmJr & $25(2,85)$ & $\mathrm{b}$ \\
MTmMs & $29(3,06)$ & $\mathrm{b}$ \\
MTmTr & $45(3,84)$ & $\mathrm{c}$ \\
MTmIn & $43(3,75)$ & $\mathrm{c}$ \\
MAgIn & $48(3,97)$ & $\mathrm{c}$ \\
Kontrol & $100(5,74)$ & $\mathrm{d}$ \\
\hline
\end{tabular}

Angka diikuti oleh huruf yang sama pada kolom yang sama berbeda tidak nyata pada taraf uji BNJ 5\%. Data dalam kurung merupakan data transformasi arcsine akar $\mathrm{x}$.

Menurut Boucias \& Pendland (1998) jamur entomopatogen yang masuk kedalam tubuh serangga, dianggap oleh serangga sebagai non-self kemudian respon immun diaktifkan yaitu suatu respon yang dibuat oleh sistem immun serangga untuk mengatasi invasi organisme asing.

Lethal Time $\left(\mathbf{L T}_{50}\right) \cdot \mathrm{LT}_{50}$ merupakan batas waktu yang dibutuhkan oleh suatu zat untuk membunuh 50\% serangga uji. Hasil peneitian menunjukan $\mathrm{LT}_{50}$ terendah ditemukan pada isolat BPluS yaitu 2,09 hari dengan ratarata mortalitas $83 \%$, dan nilai $\mathrm{LT}_{50}$ tertinggi pada isolat BNIPTr yaitu 4,33 hari dengan rata-rata mortalitas $41 \%$ (Tabel 11). Menurut Herlinda et al. (2006) $\mathrm{LT}_{50}$ merupakan waktu yang dibutuhkan isolat dari sejak infeksi hingga serangga mati. Semakin rendah nilai $\mathrm{LT}_{50}$ semakin virulen isolat karena itu nilai $\mathrm{LT}_{50}$ dapat menentukan potensi isolat tersebut.

Sedangkan pada isolat M.anisopliae menunjukan $\mathrm{LT}_{50}$ terendah ditemukan pada isolat MAgPd yaitu 2,26 hari dengan rata-rata mortalitas $82 \%$, dan $\mathrm{LT}_{50}$ tertinggi pada isolat MAgIn yaitu 3,86 hari dengan rata-rata mortalitas $46 \%$ (Tabel 12).

Terdapat hubungan antara $\mathrm{LT}_{50}$ dengan kerapatan spora. $\mathrm{LT}_{50}$ terendah ditemukan pada isolat $B$. bassiana adalah isolat BPluS yaitu 2,09 hari, memiliki kerapatan spora tertinggi yaitu $3,64 \times 10^{7} \mathrm{konidia} / \mathrm{ml}$, dan menyebabkan mortalitas juga tinggi yaitu $83 \%$, sedangkan pada isolat $M$. anisopliae adalah isolat MAgPd yaitu 2,09 hari, memiliki kerapatan spora tertinggi yaitu $3,63 \times 10^{7} \mathrm{konidia} / \mathrm{ml}$, dan menyebabkan mortalitas juga tinggi yaitu $82 \%$ 
Tabel 11. $\mathrm{LT}_{50}$ dari larva $P$. xylostella setelah aplikasi $B$. bassiana

\begin{tabular}{lccc}
\hline \multicolumn{1}{c}{ Isolat } & Mortalitas $(\%)$ & LT $_{50}$ (hari) & Regresi \\
\hline BPluS & 83,00 & 2,09 & $\mathrm{y}=-1.351+0.648 \mathrm{x}$ \\
BTmS1 & 66,00 & 2,79 & $\mathrm{y}=-1.421+0.510 \mathrm{x}$ \\
BubS2 & 79,00 & 2,50 & $\mathrm{y}=-1.624+0.649 \mathrm{x}$ \\
BpluTb & 70,00 & 2,56 & $\mathrm{y}=-1.361+0.532 \mathrm{x}$ \\
BTmTb1 & 46,00 & 3,93 & $\mathrm{y}=-1.411+0.359 \mathrm{x}$ \\
BUbTb2 & 44,00 & 4,00 & $\mathrm{y}=-1.392+0.348 \mathrm{x}$ \\
BPluKn & 42,00 & 4,16 & $\mathrm{y}=-1.462+0.351 \mathrm{x}$ \\
BTmKn1 & 50,00 & 3,62 & $\mathrm{y}=-1.396+0.386 \mathrm{x}$ \\
BUbKn2 & 42,00 & 2,97 & $\mathrm{y}=-1.463+0.352 \mathrm{x}$ \\
BPcMs & 63,00 & 2,23 & $\mathrm{y}=-1.517+0.511 \mathrm{x}$ \\
BLePd & 81,00 & 3,17 & $\mathrm{y}=-1.431+0.642 \mathrm{x}$ \\
BTmPd & 57,00 & 3,30 & $\mathrm{y}=-1.330+0.420 \mathrm{x}$ \\
BAgTb & 55,00 & 4,33 & $\mathrm{y}=-1.410+0.427 \mathrm{x}$ \\
BNIPTr & 41,00 & & \\
\hline
\end{tabular}

$\mathrm{y}=$ peubah tidak bebas (mortalitas); $\mathrm{x}=$ peubah bebas (hari).

Tabel 12. LT $_{50}$ dari larva P. xylostella setelah aplikasi M. anisopliae

\begin{tabular}{rccc}
\hline Isolat & Mortalitas $(\%)$ & LT $_{50}$ (hari) & Regresi \\
\hline MAgPd & 82,00 & 2,26 & $\mathrm{y}=-1.538+0.681 \mathrm{x}$ \\
MTmJr & 72,00 & 2,64 & $\mathrm{y}=-1.508+0.571 \mathrm{x}$ \\
MTmMs & 71,00 & 2,61 & $\mathrm{y}=-1.446+0.553 \mathrm{x}$ \\
MTmTr & 51,00 & 3,50 & $\mathrm{y}=-1.406+0.401 \mathrm{x}$ \\
MTmIn & 52,00 & 3,44 & $\mathrm{y}=-1.368+0.397 \mathrm{x}$ \\
MAgIn & 46,00 & 3,86 & $\mathrm{y}=-1.468+0.380 \mathrm{x}$ \\
\hline
\end{tabular}

$\mathrm{y}=$ peubah tidak bebas (mortalitas); $\mathrm{x}=$ peubah bebas (hari).

Keefektifan jamur entomopatogen dalam menginfeksi inang dapat dipengaruhi oleh kerapatan spora, frekuensi aplikasi, umur inang, tempat penyimpanan jamur entomopatogen (Prayogo et al., 2005), dan media biakan (Herlinda et al., 2006)

\section{SIMPULAN}

Dari eksplorasi jamur entomopatogen ditemukan 9 isolat jamur entomopatogen dari genus $B$. bassiana di sentra produksi sayuran dataran rendah kota Palembang yaitu Suak, Talang Buruk dan Kenten. Kerapatan dan viabilitas spora tertinggi ditemukan pada isolat BPluS yang diisolasi dari P. xylostella berasal dari Suak masing-masing sebesar $3,64 \times 10^{7} \mathrm{konidia} / \mathrm{ml}$ dan $31,18 \%$. Mortalitas larva $P$. xylostella tertinggi berasal dari isolat BPluS yaitu $83 \%$, mortalitas larva P. xylostella terendah berasal dari isolat BNIPTr yaitu $41 \%$, sedangkan persentase pupa menjadi imago terendah terdapat pada isolat MAgPd sebesar $15 \% . \mathrm{LT}_{50}$ terendah ditemukan pada isolat BPluS yaitu 2,09 hari dengan ratarata mortalitas $83 \%$, dan $\mathrm{LT}_{50}$ tertinggi pada isolat BNIPTr yaitu 4,33 hari dengan rata-rata mortalitas $41 \%$.

\section{DAFTAR PUSTAKA}

Ahmad RZ, Haryuningtyas D \& Wardhana A. 2008. Lethal time 50 cendawan Beauveria bassiana dan Metarhizium anisopliae terhadap Sacoptes scabiei. Seminar Nasional Teknologi Peternakan dan Veteriner. Hlm. 498-503.

Barnett HL \& Hunter BB. 1972. Illustrated Genera of Imperfect Fungi. Third Edition. Burgess Publishing Company. Minneapolis, Minnesota.

Bouncias DG \& Pendland JC. 1998. Principles of Insect Pathology. Kluwer Academy Publisher. London. 
Chan NW, Moe KT \& Weine NNO. 2008. Study on the biology of diamondback moth Plutella xylostella (L.) on cabbage. GMSARN International Conference on Sustainable Development: Issues and Prospects for the GMS 12-14 Nov 2008. p.1-3.

Deciyanto S \& Indrayani IGAA. 2008. Jamur entomopatogen Beauveria bassiana: potensi dan prospeknya dalam pengendalian hama tungau. Perspektif 8(2): 65-73.

Ghanbary MAT, Asgharzadeh A, Hadizadeh AR \& Sharif MM. 2009. A quick method for Metarhizium anisopliae isolation from cultural soils. Am. J. Agri. \& Biol. Sci. 4(2):152-155.

Hashim N, Ibrahim YB \& Tan YH. 2002. Electron microscopy of entomopathogenic fungal invasion on the cabbage-heart caterpillar Crocidolomia binotalis Zeller (Lepidoptera: Pyralidae). AJSTD. 19: 111-125.

Hasyim A \& Azwana. 2003. Patogenisitas isolat Beauveria bassiana (Balsamo) Vuillemin dalam mengendalikan hama penggerek bonggol pisang, Cosmopolites sordidus Germar. J. Hort. 13(2): 120-130.

Herlinda S. 2004. Potensi parasitoid telur, Trichogrammatoidea sp. dalam mengatur populasi dan serangan Plutella xylostella (L.) (Lepidoptera: Plutellidae) di pertanaman sawi. Inovasi 1(1): 48-56.

Herlinda S, Sari EM, Pujiastuti Y, Suwandi, Nurnawati E \& Riyanta A. 2005. Variasi virulensi strainstrain Beauveria bassiana (Bals.) Vuill terhadap larva Putella xylostella (L.) (Lepidoptera: Plutellidae). Agritrop. 24(2): 52-57.

Herlinda S, Utama MD, Pujiastuti Y \& Suwandi. 2006. Kerapatan dan viabilitas spora Beauveria bassiana (Bals.) Vuill akibat subkultur dan pengayaan media, serta virulensinya terhadap larva Plutella xylostella (Linn.). Jurnal Hama dan Penyakit Tumbuhan Tropika 6(2): 70-78.

Herlinda S, Mulyati SI \& Suwandi. 2008. Selection of isolates of entomopathogenic fungi and the bioefficacy of their liquid production against Leptocorisa oratorius nymphs. J. Microbiol. Indones. 2(3): 141-146.
Herlinda S. 2010. Spore density and viability of entomopathogenic fungal isolates from Indonesia, and their virulence against Aphis gossypii Glover (Homoptera: Aphididae). Tropical Life Sciences Research 21(1): 13-21.

Indriyati. 2009. Virulensi jamur entomopatogen Beauveria bassiana (Balsamo) Vuillemin (Deuteromycotina, Hyphomycetes) terhadap kutudaun (Aphis spp) dan kepik hijau (Nezara viridula). J. Hama dan Penyakit Tumbuhan Tropika 9(2): 92-98.

Kalshoven LGE. 1981. The Pests of Cops in Indonesia. Revised and translated by P.A. Van der Laan. PT. Ichtiar Baru-Van Hoeve. Jakarta.

Krutmuang P \& Mekchay S. 2005. Pathogenicity of entomopathogenic fungi Metarhizium anisopliae against termites. Conference on International Agricultural Research for Development. Stuttgart-Hohenheim, October 11-13, 2005.

Lomer CJ, Bateman RP, Johnson DL, Langewald J \& Thomas M. 2001. Biological control of locusts and grasshoppers. Annu. Rev. Entomol. 46: 667702.

Mahr, SER, Cloyd RA, Mahr DL \& Sadof CS. 2001. Biology Control of Insects and the Other Pest of the Greenhouse Crop. North Central Regional Publication 581. University of WisconsinExtention, Cooperative Extention.

Nuraida \& Hasyim A. 2009. Isolasi, identifikasi, dan karakteristik jamur entomopatogen dari rizosfir pertanaman kubis. J. Hort. 19(4): 419-432.

Prayogo Y, Tengkano W \& Marwoto. 2005. Prospek cendawan entomopatogen Metarhizium anisopliae untuk mengendalikan ulat grayak Spodoptera litura pada kedelai. J. Litbang. Pertanian 24:19-26.

Sambiran WJ \& Hosang MLA. 2007. Pertumbuhan cendawan Metarhizium anisopliae (Metch) Sorokin pada media air kelapa. Buletin Palma No. 33, Desember 2007. Hlm. 9-17.

Sheroze A, Rashid A, Shakir AS \& Khan SM. 2003. Effect of bio-control agents on leaf rustof wheat and influenceof different temperature and humidity levels on their colony growth. Int. J. Agri. Biol. 5(1): 83-85. 
Suharto, Trisusilowati EB \& Purnomo H. 1998. Kajian aspek fisiologik Beauveria bassiana dan virulensinya terhadap Helicoverpa armigera. Jurnal Perlindungan Tanaman Indonesia 4(2): 112-119.

Surtikanti \& Yasin M. 2009. Keefektifan entomopatogenik Beauveria bassiana Vuill. dari berbagai media tumbuh terhadap Spodoptera litura F. (Lepidoptera: Noctuidae) di laboratorium. Prosiding Seminar Nasional Serealia. Hlm. 358-362.

Wahyono TE \& Tarigan N. 2007. Uji patogenisitas agen hayati Beauveria bassiana dan Metarhizium anisopliae terhadap ulat serendang (Xystrocera festiva). Buletin Teknik Pertanian. 12(1): 27-29.

Wai CN, Thu MK \& Oo WNN. 2008. Study on the biology of diamondback Moth,Plutella xylostella (L.), on cabbage. GMSARN International Conference on Sustainable Development: Issues and Prospects for the GMS. 12-14 Nov. p.1-3.
Wang XG, Duff J, Keller MA, Zalucki MP, Liu SS \& Bailey P. 2004. Role of Diadegma semiclausum (Hymenoptera: Ichneumonidae) in controlling Plutella xylostella (Lepidoptera: Plutellidae): cage exclusion experiments and direct observation. Biocontrol Science and Technology 14(6): 571-586.

Winasa IW \& Herlinda S. 2003. Population of Diamondback Moth, Plutella xylostella L. (Lepidoptera:Yponomeutidae), and Its Damage and Parasitoids on Brassicaceous Crops. Proceedings of an International Seminar on Organic Farming and Sustainable Agriculture in the Tropics and Subtropics. Palembang October 8-9, 2003. 